\title{
Reproduction in females of the little free-tailed bat, Tadarida (Chaerephon) pumila, in the eastern Transvaal, South Africa
}

\author{
M. van der Merwe, I. L. Rautenbach* and W. J. van der Colf \\ Mammal Research Institute, University of Pretoria, 0002 Pretoria, and ${ }^{*}$ Transvaal Museum, \\ P.O. Box 413,0001 Pretoria, Republic of South Africa
}

\begin{abstract}
Summary. Little free-tailed bats $(2-9 /$ month) were collected over 15 months in the eastern Transvaal lowveld (latitude $24^{\circ} 59^{\prime} \mathrm{S}$ ). There was an extended but distinct breeding season of 8 months per year. Females appeared to be polyoestrous and able to bear 3 pregnancies per breeding season. There was a progressive decrease in the magnitude of the three birth peaks during the breeding season, with a concomitant slight loss in birth synchronization. Gestation period was $\sim 60$ days and one young per female was the rule, with implantation occurring only in the right uterine horn of the bicornuate uterus. It is suggested that offspring are weaned before the age of 21 days, and that females become sexually mature in the following breeding season at the age of 5-12 months.
\end{abstract}

\section{Introduction}

The little free-tailed bat, Tadarida pumila, is, second to $T$. chapini, the smallest of the 14 species of free-tailed bats known to occur in the Southern African subregion (Smithers, 1983); the males average $10.2 \mathrm{~g}$ and the females $11.8 \mathrm{~g}$ in body mass (Rautenbach, 1982). It is a very common species with an extensive range through most of subsaharan Africa (Hayman \& Hill, 1971) but with a distinctly eastern distribution in southern Africa. Free-tailed bats (Family Molossidae) are highly gregarious or semi-gregarious by day, with colonies sheltering in caves, rock crevices, hollow trees or human dwellings (Rosevear, 1965). However, molossids are difficult subjects to study. By day they are elusive, whereas by night they fly fast and high.

In the Transvaal, the little free-tailed bat, has most often been recorded roosting in human dwellings, in many instances from under corrugated iron roofs (Rautenbach, 1982). This species is highly gregarious, with colonies of up to several hundreds being recorded (Smithers \& Wilson, 1979). Several roosts are known to be occupied by the same colonies without interruption for many years, indicating that this species is non-migratory. Although it is one of the most common bats in Africa, its breeding biology is relatively unknown. The most comprehensive study so far conducted on reproduction of African tadarids was by Mutere (1973a) in the equatorial climate of Uganda, involving a comparative study between $T$. condylura and $T$. pumila. In the Southern African subregion information pertaining to the reproduction cycles of any tadarid species is meagre. Rautenbach (1982) collected $T$. pumila females in the Transvaal and found 13 pregnant during November and 9 lactating during December. In northern Botswana Smithers (1971) recorded pregnancies for this species from August to February with a distinct peak during December.

The purpose of the present study was to obtain a clearer picture of the reproductive strategy of the little free-tailed bat in the temperate conditions of southern latitudes. 


\section{Materials and Methods}

During the period September 1983 to November/December 1984 about 6 little free-tailed bats ( Tadarida pumila) females were collected at the end of each month at Skukuza $\left(24^{\circ} 59^{\prime} \mathrm{S}, 31^{\circ} 35^{\prime} \mathrm{E}\right)$ in the Kruger National Park, situated in the eastern Transvaal lowveld. Conservation interests precluded larger samples. The bats were trapped early evenings upon departure from their daytime roosts by suspending a large plastic bag immediately below the exit. The bats were collected from a number of large and established colonies roosting in the roofs of staff houses in the Skukuza township, especially where their presence reached nuisance proportions. At the field laboratory the bats were killed with technical ether. Female reproductive tracts with either no or small embryos were fixed in Bouin's fluid for histological examination. Big fetuses were stored in a mixture of $95 \%$ ethyl alcohol, $40 \%$ formalin, glacial acetic acid and distilled water (3:1:1:5 by vol.) or in 10\% buffered formalin. All other uteri together with the ovaries were sectioned at $8 \mu \mathrm{m}$ or $5 \mu \mathrm{m}$, and the serially mounted sections were stained with haematoxylin and eosin.

The skulls of all animals taken were collected and catalogued as regular specimens in the study collection of the Transvaal Museum. The cleaned skulls were examined to verify field identifications as well as to ascertain whether all individuals had attained adulthood.

The gestation period for this species was taken as 60 days. The most accurate method available to us to determine the length of gestation was by noting the time interval between the earliest conception, as viewed microscopically, and the first subsequent appearance of a full-term fetus and this appeared to be approximately 60 days.

Fetal age was determined by using the Huggett \& Widdas (1951) equation, $\mathrm{W}^{\frac{1}{3}}=a\left(t_{\mathrm{g}}-t_{\mathrm{o}}\right)$ for mammalian fetal growth, where $W^{\frac{1}{3}}$ is the cube root of fetal mass $(\mathrm{g}) ; a$ is the specific fetal growth velocity; $t_{\mathrm{g}}$ is the gestation period and $t_{\mathrm{o}}$ is the value where the linear plot when lengthened backwards intercepts the time axis. The $t_{\mathrm{o}}$ value can be determined by multiplying the gestation period of a species with the $t_{\mathrm{o}}$ values calculated for various gestation lengths by Huggett \& Widdas (1951).

The mass of the heaviest fetus recorded was taken as the birth mass for this species, i.e. $3 \cdot 2 \mathrm{~g}$. With a gestation period $\left(t_{\mathrm{g}}\right)$ of 60 days, a birth mass of $3.2 \mathrm{~g}\left(\mathrm{~W}^{\frac{1}{3}}=1,47\right)$, a $t_{\mathrm{o}}$ value of $60 \times 0.30=18$, the specific growth velocity $(a)$ for $T$. pumila was calculated to be 0.035 . Therefore, with $\mathrm{W}^{\frac{1}{3}}=a\left(t_{\mathrm{g}}-t_{\mathrm{o}}\right)$, the age of all fetuses collected was calculated with the equation $t=\frac{\mathrm{W}^{\frac{1}{3}}}{0.035}+18$.

\section{Results}

The little free-tailed bat female has a bicornuate uterus with both uterine horns similar in size. Embryos and fetuses were without exception recorded in the right uterine horn and each female had only one fetus. Implantation was superficial with the placenta orientated in a mesometrial direction. No transmigration of the conceptus was found, all of the oocytes originating from the right ovary. Examination of serial sections of 18 uteri (with embryos and small fetuses) and both their ovaries revealed that all of the corpora lutea were located in the right ovary (Fig. 1). Pregnancies were recorded for 8 months of the year from August/September to March/April (Table 1; Fig. 1). From Fig. 2 it is apparent that from the second half of September to the first half of April $93 \%$ of the females examined ( 54 out of 58 specimens) were pregnant. Because pregnant females were collected over an 8 -month period with nearly $100 \%$ of the females pregnant for 7 months of that time, and considering the gestation period, it appears highly likely that this species is polyoestrous and therefore the possibility of post-partum pregnancies should be considered. None of the 33 females collected during the period 25 April to 26 July 1984 showed any signs of reproductive activity. 
Table 1. Reproductive status of little free-tailed bat females ( $T$. pumila) collected from October 1983 to December 1984

\begin{tabular}{|c|c|c|c|}
\hline \multirow[b]{2}{*}{ Date } & \multirow{2}{*}{$\begin{array}{l}\text { Total } \\
\text { no. of } \\
\text { females }\end{array}$} & \multicolumn{2}{|r|}{ Pregnant females } \\
\hline & & No. & Status of embryos/fetuses \\
\hline 5 Oct. 1983 & 7 & 6 & $\begin{array}{l}\text { Fetuses (6): at limb-bud stage (mounted and serially sectioned, mass not } \\
\text { taken) }\end{array}$ \\
\hline 25 Oct. 1983 & 7 & 7 & Fetuses (7): $0.54 \mathrm{~g} ; 0.68 \mathrm{~g} ; 0.71 \mathrm{~g} ; 0.73 \mathrm{~g} ; 0.89 \mathrm{~g} ; 0.90 \mathrm{~g} ; 0.91 \mathrm{~g}$ \\
\hline 27 Nov. 1983 & 5 & 4 & Embryos (3): zygote; 6-8 cell-stage; young morula; fetus (1), $1 \cdot 15 \mathrm{~g}$ \\
\hline 29 Dec. 1983 & 2 & 2 & Fetuses (2): $0.31 \mathrm{~g} ; 0.26 \mathrm{~g}$ \\
\hline 25 Jan. 1984 & 6 & 6 & Fetuses (6): $0.03 \mathrm{~g} ; 0.04 \mathrm{~g} ; 2.51 \mathrm{~g} ; 2.52 \mathrm{~g} ; 2.78 \mathrm{~g} ; 3.19 \mathrm{~g}$ \\
\hline 28 Feb. 1984 & 8 & 8 & Fetuses $(8): 0.02 \mathrm{~g} ; 0.04 \mathrm{~g} ; 0.04 \mathrm{~g} ; 0.06 \mathrm{~g} ; 0.07 \mathrm{~g} ; 0.07 \mathrm{~g} ; 0.08 \mathrm{~g} ; 3.12 \mathrm{~g}$ \\
\hline 31 Mar. 1984 & 3 & 3 & Fetuses (3): $1.06 \mathrm{~g} ; 1.59 \mathrm{~g} ; 1.89 \mathrm{~g}$ \\
\hline 25 Apr. 1984 & 8 & 0 & \\
\hline 5 June 1984 & 8 & 0 & \\
\hline 23 June 1984 & 8 & 0 & \\
\hline 26 July 1984 & 9 & 0 & \\
\hline 4 Sept. 1984 & 6 & 4 & Embryos (4): one zygote and three 4-6-cell stages \\
\hline 30 Sept. 1984 & 5 & 5 & Fetuses (5): $0.02 \mathrm{~g} ; 0.03 \mathrm{~g} ; 0.03 \mathrm{~g} ; 0.08 \mathrm{~g} ; 0.14 \mathrm{~g}$ \\
\hline 2 Nov. 1984 & 5 & 5 & Fetuses (5): $0.06 \mathrm{~g} ; 2.28 \mathrm{~g} ; 2.29 \mathrm{~g} ; 2.37 \mathrm{~g} ; 3.12 \mathrm{~g}$ \\
\hline 4 Dec. 1984 & 4 & 4 & $\begin{array}{l}\text { Fetuses (4): at limb-bud stage (mounted and serially sectioned, mass not } \\
\text { taken) }\end{array}$ \\
\hline
\end{tabular}

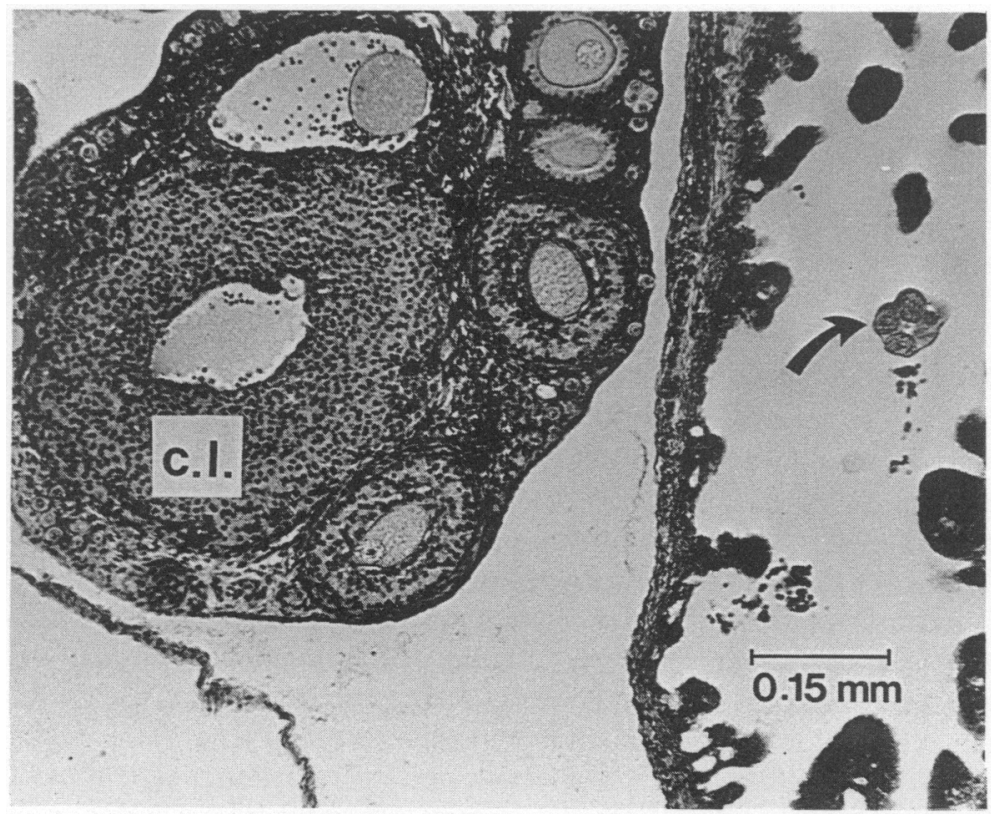

Fig. 1. Right ovary with young corpus luteum (c.l.) and part of the right oviduct of a female little free-tailed bat containing a 4-cell stage embryo (indicated by arrow). 


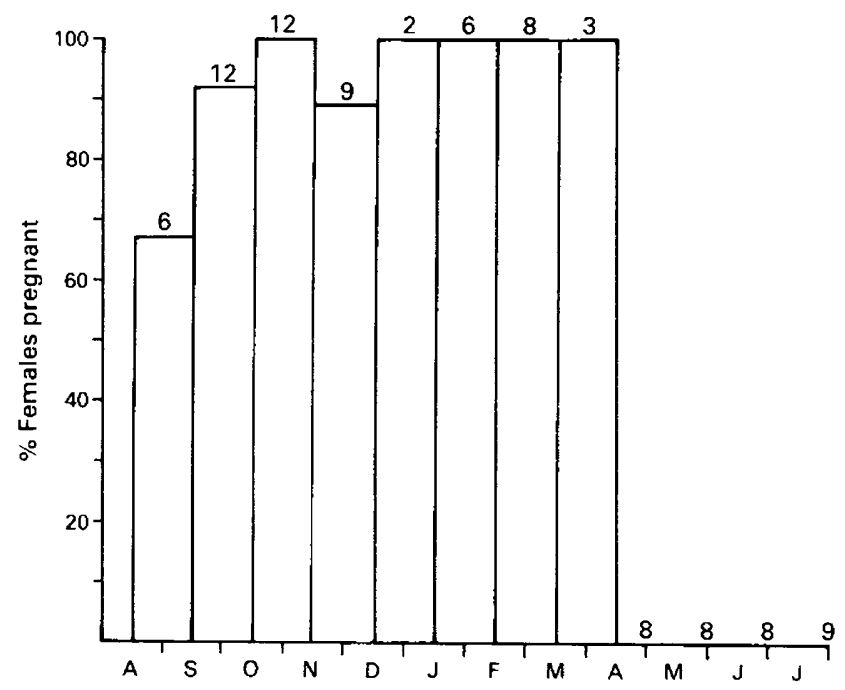

Fig. 2. Percentages of pregnant females collected during the various months of the year. Monthly sample sizes are given above the histogram.

Seasonal ovulation and conception had occurred during the first half of September in most of the females, although a few appeared to have begun breeding during the last half of August (see below). On 4 September 1984, 6 females were collected. Of these, 4 had 1 very small embryo each (ranging from a zygote to 4- and 6-cell stages) in the right oviduct and a corpus luteum in the right ovary (Table 1; Fig. 1). One of the other 2 females had a mature Graafian follicle in the right ovary that probably would have ruptured within a few days while the second non-pregnant female had a medium-sized Graafian follicle in the right ovary. The last pregnant females of the season were collected on 31 March 1984 (Table 1). As estimated by their calculated ages the fetuses of the latter would have been born during the first half of April. None of the females collected during the winter months, from the second half of April until the end of July were pregnant (Table 1). Therefore, by taking the last half of August into consideration as the period when copulation started, the breeding season in $T$. pumila is deduced to be 8 months of the year. It is not known at what age juveniles become independent of their mothers, but this is not expected to exceed 3 weeks of age (see 'Discussion'). It is therefore possible for a female to produce 3 young per season.

Of the 58 females collected during the established breeding season, only 4 were not pregnant (Table 1). One of the sample of 7 females collected on 5 October 1983 was not pregnant. This particular individual was very young as judged by toothwear and the open state of skull sutures, and was therefore believed to be an offspring from the previous breeding season. On 27 November 1983,1 of the 5 females collected was not pregnant. Judged by toothwear she was fully mature. However, she had a post-partum uterus, indicating recent reproductive activity. Furthermore, on 4 September 1984, 2 of the 6 females collected (Table 1) were not pregnant. As mentioned above, one (a fully mature individual) had a ripe Graafian follicle in the right ovary and only small follicles in the left ovary. The remaining non-pregnant female, a very young individual as judged by toothwear and the open state of the skull sutures, had a medium-sized Graafian follicle in the right ovary with only small follicles in the left ovary. The 4 pregnant females from this sample were also very young, by the same criteria, and the occurrence of these 4 very young pregnant females collected at the beginning of the breeding season strongly suggests that females become reproductively active during the first breeding season after birth, i.e. between the ages of 5 and 12 months. The 2 non-pregnant females from this particular sample exhibited potential reproductive activity. 


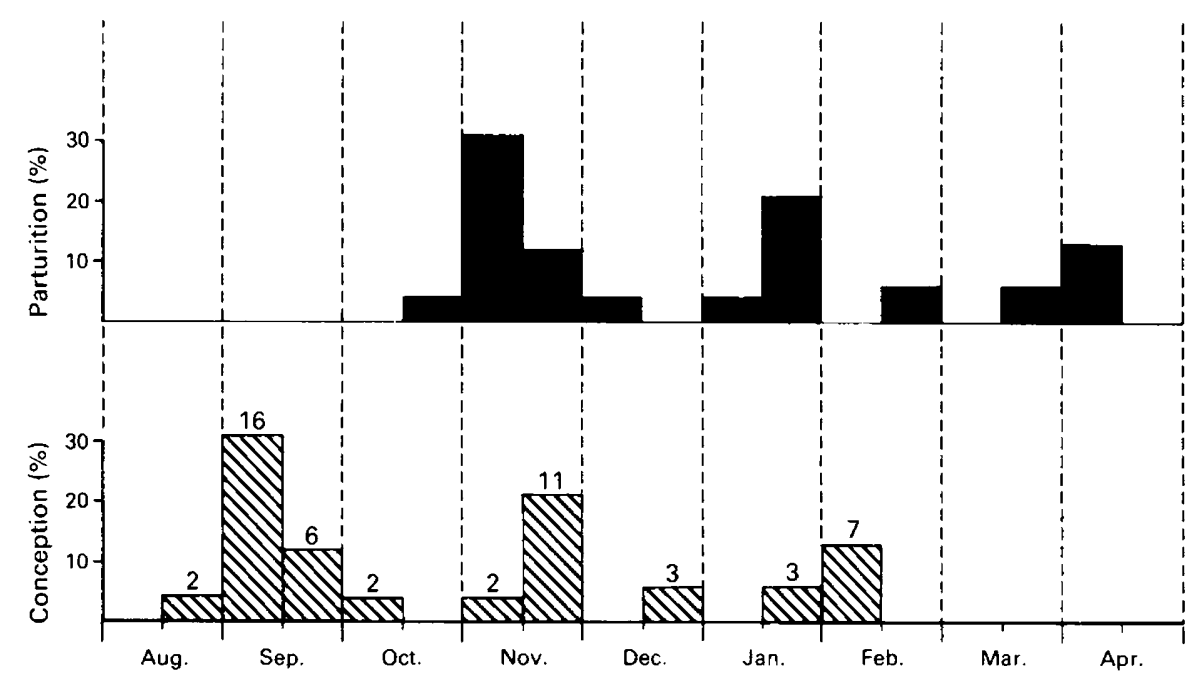

Fig. 4. Derived monthly percentages of ovulations/conceptions and parturitions of $T$. pumila $(n=52)$. Monthly sample sizes are given above the lower histogram.

pattern of birth (Fig. 4). Hence, $5 \%$ of all observed pregnancies would have terminated in births during the last half of October, whereas the birth rate would have peaked with $31 \%$ of the seasonal total during the first half of November. The last births of the season would have occurred during the first 2 weeks of April. Not all females conceived three times per breeding season, as can be seen in Fig. 4 from the descending pattern of the three distinct birth peaks.

\section{Discussion}

Tadarida is one of the most diverse genera amongst the African microchiropterans, and some species are very widespread and common, like $T$. pumila. However, free-tailed bats are elusive in their roosting habits, and furthermore fly fast and high out of human reach. As a consequence specimens are not easily obtainable, as is reflected by the dearth of information on the breeding cycles of tadarids. Available information is mostly fragmentary (Harrison, 1958; Asdell, 1965; Smithers, 1971; Rautenbach, 1982). Two of the more comprehensive studies on African molossids were conducted by Mutere (1973a, b) near the equator: $T$. pumila was reported to be aseasonally polyoestrous, $T$. condylura to be seasonally polyoestrous and Otomops martiensseni to be seasonally monoestrous. Marshall \& Corbet $(1959)$ have shown that Chaerephon hindei $(=T$. (Chaerephron) pumila of Hayman \& Hill, 1971; and Chaerephon pumila of Freeman, 1981) also breeds throughout the year at Jinja near the equator. They found unmistakable evidence that within the general pattern of continuous reproduction throughout the year there are groups of females that are in reproductive synchronization. We have found the same phenomenon with $T$. pumila in the Kruger National Park (Fig. 4). Our data strongly suggest that synchronized breeding begins during mid-August to mid-September at the beginning of a sharply defined breeding season, when 4 of the 6 females in the monthly sample had conceived and the remaining 2 had developing Graafian follicles. After an initial synchronized gestation period, synchronization amongst some females will be possible during subsequent breeding cycles for that season. In T. pumila, however, there is an indication that this synchronization decreases as the breeding season progresses (Fig. 4). Females of this species become sexually mature at 5-12 months of age. This agrees closely with the 
findings of Pagels \& Jones (1974), Short (1961) as well as Sherman (1937) who found females of congener $T$. brasiliensis to reach sexual maturity at 9 months of age. Marshall \& Corbet (1959) suggested reproduction at a very early age in $C$. hindei $(=T$. pumila $)$. In the Transvaal lowveld at latitude $24^{\circ} 59^{\prime} \mathrm{S}$ our data strongly suggest that $T$. pumila females are seasonally polyoestrous, and able to conceive as many as 3 times per breeding season. This conclusion is verified by Harrison (1958) who reported post-partum oestrus in an adult $T$. pumila female collected at Maiduguri in Nigeria. This female was lactating while carrying a very small fetus in the uterus. Harrison (1958) further mentioned that a similar condition was suggested for a specimen collected at Margherita, Somalia, although it was not histologically confirmed. We believe $T$. pumila to be polyoestrous because in 8 of the 11 monthly samples taken during the breeding season, $100 \%$ of the females were pregnant (Table 1). If this had been a monoestrous species with such a long breeding season ( 8 months), different females will become pregnant at different times of the breeding season. Each sample should then at least contain a fair proportion of non-pregnant females. Although Harrison (1958) has confirmed post-partum oestrus in a single $T$. pumila female, we have not as yet demonstrated it in Southern African T. pumila and are currently examining this possibility. The possibility of a complete embryonic arrest or very slow embryonic development during the lactational phase, both leading to an increased gestation period, will also be checked. Since such an influence would only be effective from the second seasonal pregnancy, the calculated gestation period of 60 days for $T$. pumila during the first pregnancies of the breeding season will be the minimum gestation period for any pregnancies of the season.

Although we lack direct evidence it is expected that postnatal care will not exceed 3 weeks. In many vespertilionids postnatal care is 2-3 weeks in duration. O'Farrell \& Studier (1973) recorded flight in young Myotis thysanodes at 16.5 days of age and 14-15 days in M. lucifugus. Kunz (1973) recorded 3 weeks for $M$. velifer and Davis, Barbour \& Hassell (1968) 3 weeks for Eptesicus fuscus. Our study has shown three birth peaks 2.5 months apart and declining in magnitude as the breeding season progresses (Fig. 4). Three gestation periods of 2 months duration each per 8 months active breeding season leaves a period of $\sim 21$ days between each peak for postnatal maternal care. Rautenbach (1982) recorded pregnancies during November and lactation during December. These claims were supported by voucher specimens and the details are as follows: All of 13 females collected at TenBosch Estates, $10 \mathrm{~km} \mathrm{NE}$ Hectorspruit $\left(25^{\circ} 20^{\prime} \mathrm{S} ; 31^{\circ} 50^{\prime} \mathrm{E}\right)$ on 12 November 1974 were pregnant in the right uterine horn with single near full-term fetuses $(\sim 23-26 \mathrm{~mm})$. On 12 December 1974 all 9 females taken on the Farm Leeuwspoor, Golela district $\left(27^{\circ} 25^{\prime} \mathrm{S} ; 31^{\circ} 52^{\prime} \mathrm{E}\right)$ were lactating. These observations coincide exactly with the overall breeding pattern derived from the Skukuza material, with distinct spring and summer seasons and complete cessation of reproductive activities during winter. Skutch (1950), Janzen \& Schoener (1968) and Mutere (1973a) found insect abundance highest during rainfall peaks and concluded that parturition, lactation and weaning of bats are geared to gain maximum benefit from such wet periods of high food abundance. The effect of temperature was not discussed. Our own unquantified observations on the seasonal abundance of insects and its inferred effect on the breeding seasonality of $T$. pumila at Skukuza, support these claims in general.

The three peaks demonstrated in both conceptions and births do not coincide with any particular peaks in rainfall or temperature, although the majority of births $(78 \%)$ would have occurred during the months November to February when summer rainfall is at its maximum. We believe that the minimum temperature may play a more significant role in the onset of breeding activity as it has a direct effect on insect abundance. Mean maximum monthly temperature varies very little, from $25.9^{\circ} \mathrm{C}$ in July to $32.3^{\circ} \mathrm{C}$ in December, January and February. Mean minimum temperature, however, varies considerably from $5^{\circ} \mathrm{C}$ in July to $20.7^{\circ} \mathrm{C}$ in January (Fig. 5). From August to September there is a sharp increase in minimum temperature, which is thereafter followed by a steady increase to a peak during January (Fig. 5). During the established period of breeding activity from September to April, mean minimum temperatures were $13^{\circ} \mathrm{C}$ and above. During the months 


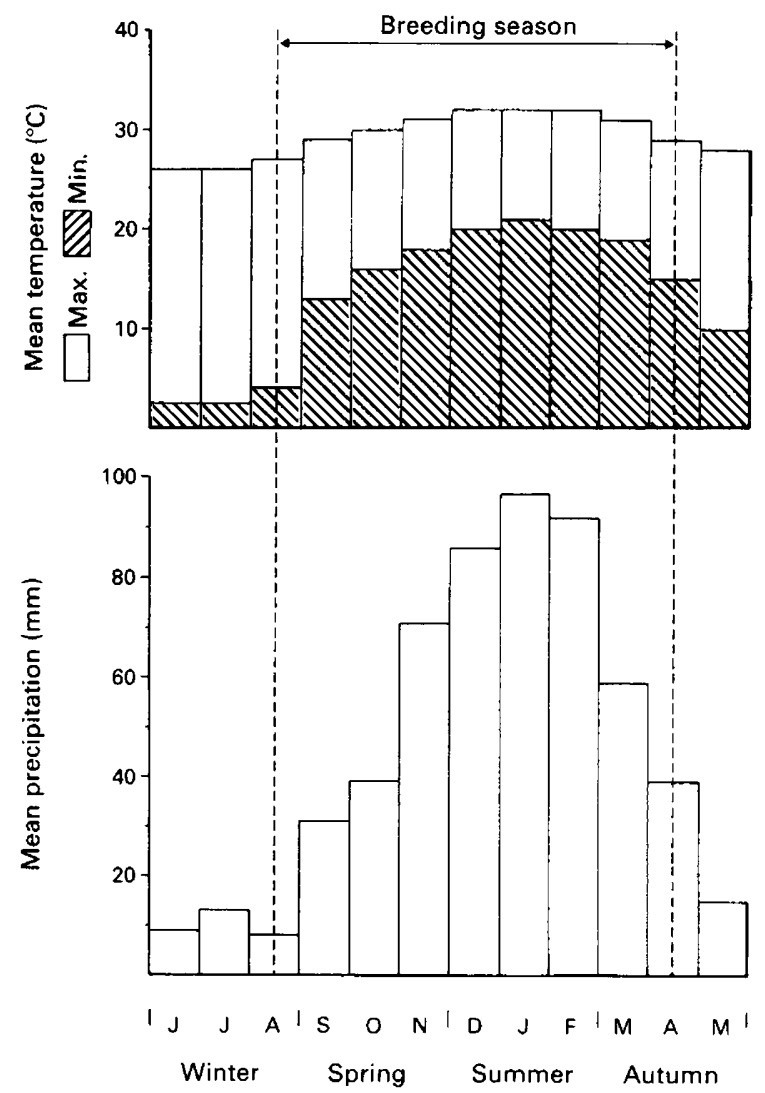

Fig. 5. Mean monthly rainfall and the mean minimum and maximum temperatures for Skukuza during the period 1951-1984. (Weather data obtained from the Weather Bureau, Pretoria.)

November to February, $78 \%$ of $T$. pumila births occur, and during this time mean monthly minimum temperatures vary between 18.0 and $21 \cdot 0^{\circ} \mathrm{C}$. Parturition and weaning place additional energy stress on a female. The above arguments, as well as personal observations on the seasonal and nocturnal aereal insect abundance as related to ambient temperatures, strongly suggest that breeding activity in $T$. pumila is geared to coincide with a period of maximum insect abundance, both in terms of the females' energy budgets as well as in the interests of newly weaned offspring starting to fend for themselves.

Molossids are the bats with the most profound and widely encountered expression of reproductive asymmetry with the right ovary and uterine horn dominant over the left (Wimsatt, 1979). Unilateral implantation in the right uterine horn of only one conceptus at a time appears to be the norm for all members of the genus Tadarida so far investigated, with the possible exception of $T$. midas (see below). Mutere $(1973 \mathrm{a}, \mathrm{b})$ has recorded one fetus at a time in all three molossid species examined by him; in all instances implantations were exclusively in the right uterine horn. This trend has also been observed for $T$. condylura and $T$. pumila by Smithers (1971); T. pumila by Rautenbach (1982); T. brasiliensis by Stephens (1962); T. brasiliensis mexicana by Jerrett (1979); $T$. cynocephala $(=T$. brasiliensis) by Sherman (1937); and T. australis by Kitchener \& Hudson (1982). However, Smithers (1971) has found one fetus in the left uterine horn in each of 14 T. midas females.

No newborn little free-tailed bats were collected in the present study, and consequently the 
highest fetal mass $(3 \cdot 2 \mathrm{~g})$ was taken as the birth mass. Mutere (1973a) has found the highest $T$. pumila fetal mass to be $3.5 \mathrm{~g}$. It is believed that full term fetal mass is a more accurate indication of the birth mass than that of newborns, as result of a drop in mass immediately after birth. Minot $(1891,1907)$ attributed it to a decrease in the power of growth resultant from the physiological shock of being born. Hammond \& Marshall (1958) mention the loss of water by evaporation shortly after birth as a causal factor. The fetal growth velocity of $T$. pumila was found to be 0.035 , which falls well within the range of 0.01-0.09 given for Chiroptera by Frazer \& Huggett (1974).

T. pumila is undoubtedly one of the commonest bats in the eastern Transvaal lowveld, with a marked predilection for colonizing human habitations. Hence $T$. pumila population densities also appear to increase concordantly with that of man, sometimes to the point where it has reached nuisance levels. Its relative high population density can, at least partly, be ascribed to its exceptional breeding potential in that each female can potentially produce a maximum of three young per season from its first year of life.

We thank the Head of the Kruger National Park, Dr U. de V. Pienaar and Dr V. de Vos (Assistant Head: Research) for permission to conduct this research in the Kruger National Park as well as for facilities at Skukuza; Dr L. E. O. Braack (Department of Research and Information of the National Parks Board) for collecting the specimens every month and for bringing them to Pafuri where they were processed at the field station; Mr L. Hare (Pafuri ranger) for supporting this and other projects in various ways; and $\mathrm{Mr} \mathrm{D}$. Coetzer and $\mathrm{Mr} \mathrm{D}$. A. Wolhuter for their assistance in the collection and preservation of material. This project was financed by a CSIR Foundation for Research Development grant-in-aid to I.L.R.

\section{References}

Asdell, A.S. (1965) Patterns of Mammalian Reproduction. London, Constable \& Co. Ltd.

Davis, W.H., Barbour, R.W. \& Hassell, M.D. (1968) Colonial behaviour of Eptesicus fuscus. J. Mammal. 49, $44-50$.

Frazer, J.F.D. \& Huggett, A.St.G. (1974) Species variations in the foetal growth rates of eutherian mammals. J. Zool., Lond. 174, 481-509.

Freeman, P.W. (1981) A multivariate study of the Family Molossidae (Mammalia, Chiroptera): morphology, ecology, evolution. Fieldiana Zoology, New series, No. 7, 1-173.

Hammond, J. \& Marshall, F.H.A. (1958) The life-cycle. In Marshall's Physiology of Reproduction, 3rd edn, vol. 2, pp. 793-846. Ed. A. S. Parkes. Longmans, London.

Harrison, D.L. (1958) A note on successive pregnancies in an African bat. Mammalia 22, 592-595.

Hayman, R.W. \& Hill, J.E. (1971) Order Chiroptera. In The Mammals of Africa: an Identification Manual, part 2, pp. 1-73. Eds J. Meester \& H. W. Setzer, Smithsonian Institution, Washington.

Huggett, A.St.G. \& Widdas, W.F. (1951) The relationship between mammalian foetal weight and conception age. J. Physiol., Lond. 144, 306-317.

Janzen, D.H. \& Schoener, T.W. (1968) Differences in insect abundance and diversity between wetter and drier sites during a tropical dry season. Ecology 49, 96-110.

Jerrett, D.P. (1979) Female reproductive patterns in nonhibernating bats. J. Reprod. Fert. 56, 369-378.
Kitchener, D.J. \& Hudson, C.J. (1982) Reproduction in the female white-striped mastiff bat, Tadarida australis (Gray) (Molossidae). Austr. J. Zool. 30, 1-14.

Kunz, T.H. (1973) Population studies of the bat (Myotis velifer): Reproduction, growth, and development. Occ. Pap. Mus. Nat. Hist. Univ. Kansas. 15, 1-43.

Marshall, A.J. \& Corbet, P.S. (1959) The breeding biology of equatorial vertebrates: reproduction of the bat Chaerephon hindei Thomas at latitude $0^{\circ} 26^{\prime} \mathrm{N}$. Proc. zool. Soc. Lond. 132, 607-616.

Minot, C.S. (1891) Senescence and rejuvenation. I. On the weight of guinea-pigs. J. Physiol., Lond. 12, 7-153.

Minot, C.S. (1907) The problem of age, growth and death. Pop. Sci. Monogr. 71, 193-216.

Mutere, F.A. (1973a) Reproduction in two species of equatorial free-tailed bats (Molossidae). E. Afr. Wildl. J. 11, 271-280.

Mutere, F.A. (1973b) A comparative study of reproduction in two populations of the insectivorous bat Otomops martiensseni, at latitudes $1^{\circ} 5^{\prime} \mathrm{S}$ and $2^{\circ} 30^{\prime} \mathrm{S}$. J. Zool., Lond. 171, 7992.

O'Farrell, M.J. \& Studier, E.H. (1973) Reproduction, growth and development in Myotis thysanodes and M. lucifugus (Chiroptera: Vespertilionidae). Ecology 54, 18-30.

Pagels, C.F. \& Jones, C. (1974) Growth and development of the free-tailed bat, Tadarida brasiliensis cynocephalus (LeConte). Southwest. Nat. 19, 267-276.

Rautenbach, I.L. (1982) Mammals of the Transvaal. Ecoplan Monograph No. 1. Colbyn, Pretoria. 
Rosevear, D.R. (1965) The Bats of West Africa. Trustees of the British Museum (Natural History), London.

Sherman, H.B. (1937) Breeding habits of the free-tailed bat. J. Mammal. 18, 176-187.

Short, H.L. (1961) Growth and development of Mexican free-tailed bats. Southwest. Nat. 6, 156-163.

Skutch, A.F. (1950) The nesting seasons of Central American birds in relation to climate and food supply. Ibis 92, 185-222.

Smithers, R.H.N. (1971) The mammals of Botswana. Mus. Mem. Natl. Mus. Monum. Rhod. 4, 1-340.

Smithers, R.H.N. (1983) The Mammals of the Southern African Subregion. University of Pretoria, Pretoria.
Smithers, R.H.N. \& Wilson, V.J. (1979) Check list and atlas of the mammals of Zimbabwe/Rhodesia. Mus. Mem. Natl. Mus. Monum. Rhod. 9, 1-147.

Stephens, R.J. (1962) Histology and histochemistry of the placenta and fetal membranes in the bat. Tadarida brasiliensis cynocephala (with notes on maintaining pregnant bats in captivity). Am.J. Anat. 111, 259-285.

Wimsatt, W.A. (1979) Reproductive asymmetry and unilateral pregnancy in Chiroptera. $J$. Reprod. Fert. 56, 345-357.

Received 31 July 1985 